DOI: $10.30519 /$ ahtr.833629

Advances in Hospitality and Tourism Research (AHTR)

\title{
UNDERSTANDING AIRLINE ORGANIZATIONAL ATTRACTIVENESS USING INTERPRETIVE STRUCTURAL MODELLING
}

\author{
Sanaz VATANKHAH ${ }^{1}$ \\ Department of International Business, Marketing and Tourism, University of Bedfordshire, UK \\ ORCID: 0000-0001-9604-8356 \\ Shiva ILKHANIZADEH \\ School of Tourism and Hotel Management, Cyprus International University, Mersin 10, Turkey \\ ORCID: 0000-0002-9362-663X
}

\begin{abstract}
This study investigates whether and how key components of organizational attractiveness are interrelating to impose the maximum positive impact on the air transportation job market. An expert panel was shaped to gauge judgments regarding the driving power of each criterion over the other. The results of Interpretive Structural Modelling (ISM) revealed that organizational and job characteristics are the main criteria with the most driving power in the model fostering perceived fit. In addition, corporate branding and corporate social responsibility (CSR) demonstrated the highest dependence on the other criteria. The results were further validated through Impact Matrix Crossreference Multiplication to a classification (MICMAC). The hierarchical pattern of study findings offers theoretical contributions to the study of organizational attractiveness. Practical implications of the results and study limitations are also provided.
\end{abstract}

\section{Article History}

Received 30 November 2020

Revised 25 April 2021

Accepted 30 April 2021

Published online 18 June 2021

\section{Keywords}

airline

interpretive structural model MICMAC

organizational attractiveness decision making

\section{INTRODUCTION}

Demand for air transportation services is rising globally in terms of both the market for passenger transfer and the need for freight services. According to the statistics (International Air Transport Association (IATA) annual report, 2019), there was a $7.4 \%$ increase in industry-wide revenue passenger kilometers (RPK) and a $9.7 \%$ increase in industry-wide freight tonne

\footnotetext{
${ }^{1}$ Address correspondence to Sanaz Vatankhah (PhD), Department of International Business, Marketing and Tourism, University of Bedfordshire, Luton, UK. E-mail: sanaz.vatankhah@beds.ac.uk
} 
kilometers (FTK) in 2017. Under these circumstances, rivalry in the air transportation market increases, as current and potential competitors would make considerable effort to pursue a competitive market position. It is assumed that a talented and qualified pool of employees would affect an organization's strategic performance and are considered sources of competitiveness in the market (Murray \& Ayoun, 2010). Understanding how job seekers evaluate an organization's attractiveness would enable organizations to appropriately design and manipulate organizational resources and competencies (Bohlmann et al., 2018; Turban \& Greening, 1997). This is especially important for the aviation industry, where its specific characteristics positioned this industry as a challenging environment to work in (Sohn et al., 2015). Director-General and CEO of IATA (2019, p.9), Alexandre de Juniac argues that:

"People are the key resource to take aviation forward. Our industry provides highquality jobs that add value to the economies in which they are located. Aviation careers are attractive, but there is growing concern about how the industry will find sufficient technically skilled employees quickly enough to keep pace with demand."

Accordingly, the airline industry as a subset of the transportation industry has been chosen to understand how commercial airlines can enhance organizational attractiveness to attract qualified job seekers. Since the adoption of proper strategies to attract talented job seekers to the organizations is well understood and noticed in a suitable environment (Bankins \& Waterhouse, 2019; Lewis \& Frank, 2002), the phenomenon of organizational attractiveness (OA) is receiving comprehensive attention among organizational researchers (e.g., Brunner \& Baum, 2020; CarballoPenela, 2019; Younis \& Hammad, 2020; Zhang et al., 2020). Specifically, organizations suffering from the lack of attractiveness in the job market require a general framework to guide them on improving their image among job seekers (Rynes \& Barber, 1990).

\section{Purpose of the study}

This study aims to understand the processes by which key configurational components of OA affect airline companies' attractiveness in the job market. Specifically, this study endeavors to identify the interrelations among key OA attributes to understand each criterion's characteristic regarding its driving power and dependency in the airline industry. Underpinned by the tenets of interpretive structural modeling, a list of key attributes has been initially identified through a careful review of comparative literature. The 
list was then used to design the questionnaire, which can address the interrelations using several pairwise comparisons among designated attributes. This methodological solution is widely used in tourism research (e.g., Jain \& Ajmera, 2018; Lee et al., 2015; Ranjan Debata et al., 2013) and is well known for its ability to transform complicated problems into simple interrelated decision-making levels (Attri et al., 2013; Kuo et al., 2010).

\section{Contributions of the study}

Two major contributions can be attributed to the current study. Firstly, this study used triangulation to validate the results (Hartley \& Sturm, 1997). Triangulation was applied by collecting data from different sources/methods, namely synthesis of comparative literature pertaining to key components of organizational attractiveness (i.e., qualitative approach) and experts' opinion rating the determining impact of each element on another (i.e., quantitative approach). Triangulation improves the quality of the study (Petter \& Gallivan, 2004) as well as the accuracy of findings (Denzin, 2007, 2017; Maxwell, 2012), and its application is highly recommended in tourism studies (Koc \& Boz, 2014; Vatankhah et al., 2019). This study, in addition, develops an interpretive structural model of airline organizational attractiveness (AOA) to demonstrate the interrelations among designated components of $\mathrm{OA}$ in the airline industry. Even though OA's notion has received considerable research attention, this phenomenon has been under-researched in the airline industry, and existing literature conferring to OA has not examined OA's key components' relationships. This study fills in the research gap by implementing ISM to develop AOA hierarchical framework. ISM is a powerful methodological solution to analyze interactive relationships among key configurational dimensions of a particular phenomenon (Ali et al., 2018; Attri et al., 2013; Sushil, 2012). In all, the application of methodologies as mentioned earlier to develop an interpretive structural model of AOA would be considered as a response to call for more empirical research enhancing current knowledge regarding key components of $\mathrm{OA}$ and the process by which those factors are interrelating (e.g., Bohlmann et al., 2018; Kröll et al., 2018; Sommer et al., 2017).

\section{LITERATURE REVIEW}

Job choice has long been of great interest for both scholars and practitioners as adequate knowledge of driving factors affecting job seekers' attraction to an organization would be a strategic tool for managers to design and develop appropriate organizational strategies. Based on this realization, 
several scholars have paid attention to this phenomenon from different perspectives. Starting to note the importance of organizational characteristics such as organizational size and geographical dispersion and organizational policies and strategies in attracting job seekers, Turban and Keon (1993) used interactionist perspective to study the impact of those attributes on job seekers' attraction to the organization. They have found a significant association between an organization's positive characteristics and job seekers' attraction to the organization. Mainly, organizational characteristics fostering organizational attraction have been manifested through family-friendly human resource policies (Honeycutt \& Rosen, 1997); centralization and rewards structure (Turban \& Keon, 1993); improved recruitment practices, improved employment inducements, and targeting nontraditional applicants (Rynes \& Barber, 1990); organizational values (Cable \& Judge, 1996); formal mentoring programs (Allen \& O'Brien, 2006); organizational personality and instrumental factors (Kausel \& Slaughter, 2011) and level of internationalization and centralization (Lievens et al., 2001) in comparative literature. Organizational characteristics have been used in a vast majority of studies relative to OA and is known as the most significant determinant of OA capable of attracting applicants' initial attraction to the organization (Huang et al., 2020).

Besides, the significant impact of several key attributes, including pay/salary (Lievens et al., 2001; Sohn et al., 2015); flexible work practices in terms of flexible work schedules, telecommuting and sabbaticals (Kröll et al., 2018), and quality of mentoring programs (Spitzmüller et al., 2008) have been studied by organizational scholars categorized as job characteristics. Lambert et al. (2019) cited that uncovering distinctive job characteristics would positively tackle organizational attractiveness in the job market (Rynes \& Miller, 1983). Review of relative literature further revealed another class of attention using fit perception as a key determinant of job seekers' attraction to organizations. Cable and Judge (1996) strongly recommended fit perception as a driving component of organizational attractiveness. That is, job seekers are primarily attracted to organizations (i.e., person-organization fit) and/or the job (i.e., person-job fit) with which they feel congruent in terms of norms and values (Cable \& Judge, 1996; Carless, 2005; Judge \& Cable, 1997; Lievens et al., 2001; Sohn et al., 2015; Yu, 2014). Perceived fit not only fosters organizational attraction but also affects applicants' ultimate job choice (Backhaus, 2016; Bretz \& Judge, 1994). Scholars have used two subsets of perceived fit to understand its impact on applicants' job choice (Cable \& Judge, 1996), organizational commitment 
and job motivation/satisfaction (Nur Iplik et al., 2011), organizational attraction (Judge \& Cable, 1997) and work values (Judge \& Bretz, 1992). Particularly, employees who perceive fit with their current job position are found to be healthier and high performing comparing to those who are suffering from the mismatch between their values and those of the job (Caldwell \& O'Reilly, 1990; Kristof-Brown et al., 2005; Park et al., 2011). In addition, person-organization fit appears to promote applicants' intention and actual job offer decision (Carless, 2005).

Several other factors have also been identified as drivers of organizational attraction, including organizational prestige (Highhouse et al., 2003); quality of online presence (Cober et al., 2003); recruitment advertisement, and positive word of mouth (Van Hoye \& Lievens, 2005); corporate web-site and information sources (Lambert et al., 2019; Lin, 2015; Nadler et al., 2017); corporate prestige and image (Duarte et al., 2014; Held \& Bader, 2018; Schreurs et al., 2009; Younis \& Hammad, 2020) and employee-based brand equity (Jiang \& Iles, 2011). In all, the factors mentioned above can comprise a larger component in terms of corporate branding. According to De Chernatony (1999), corporate branding utilizes organizational inputs to shape a unique characteristic for the organization and can enhance organizational attractiveness in the job market. This is especially a common practice taken by leading airlines (e.g., southwest airlines) in terms of employee branding (Miles \& Mangold, 2005).

Recently introduced to the academic literature, CSR has also been found as a significant predictor of organizational attractiveness (Duarte et al., 2014; Story et al., 2016; Waples \& Brachle, 2020), and its determining impact on organizational attractiveness is recommended in the current literature (e.g., Joo et al., 2016; Zhang et al., 2020). CSR initiatives have been categorized in three broad dimensions: environmental, social and economic issues. Environmental issues (e.g., emission reduction and aircraft noise reduction programs) are the most practiced dimension in the airline industry (Cowper-Smith \& de Grosbois, 2011). This phenomenon may take any shape and approach such as morality (van Prooijen \& Ellemers, 2015); diversity management (Albinger \& Freeman, 2000; Backhaus et al., 2002; Murray \& Ayoun, 2010; Umphress et al., 2007); human rights, employee relations, philanthropy and environment (Albinger \& Freeman, 2000; Murray \& Ayoun, 2010); perceived CSR, its motives and overall justice (Joo et al., 2016); CSR communication and advertisement (Belinda et al., 2018); sustainability (Sohn et al., 2015) and level of CSR engagement (Duarte et al., 2014). According to Belinda et al. (2018), CSR's adoption is not enough to develop organizational attractiveness, but the way organizations 
communicate their CSR initiatives also matters. Despite its strong predictive capability in many disciplines, however, "previous literature has overlooked the complex nature of the decisions that potential employees make about job choices while addressing the isolated effect of CSR on organizational attractiveness" (Lis, 2018, p. 106).

Besides the above-mentioned organizational level factors, there is some academic evidence on the impacts of personality characteristics of job seekers affecting their choice of proposed job (e.g., Held \& Bader, 2018, Kausel \& Slaughter, 2011; Lievens et al., 2001; Nadler et al., 2017; Schreurs et al., 2009; Umphress et al., 2007). In light of fit theory, specifically, Judge and Cable (1997) argued that applicants' choice of an organization is primarily based on their personal characteristics and personality traits. Accordingly, determining the impact of personality characteristics and its interaction with organizational characteristics leading to applicants' choice of an organization should be further developed (Lievens et al., 2001; Kausel \& Slaughter, 2011).

Against this backdrop yet, it appears that OA has been remained a challenging concept to explain (Backhaus et al., 2002). Specifically, a review of comparative literature revealed that no general framework exists to clarify the process by which OA components may interact with each other. According to Helmreich and Foushee (2010, p.17), "the fact that process variables have been largely ignored in research does not indicate a lack of awareness of their importance; rather, it reflects the difficulty of conceptualizing and measuring them." Under this circumstance, this study bridges the research gap by proposing significant OA components and analyzing the interrelations among those components. In addition, this study contributes to tourism management literature by proposing the hierarchical model of OA in the airline industry, which is currently known as a challenging place for talented graduates (Sohn et al., 2015).

\section{METHODOLOGY}

This study uses the ISM technique to understand how OA's key configurational components are interrelating with each other. This procedure identifies each factor's position in terms of their ability to affect other factors (i.e., driving power) or, in contrast, to be manipulated by independent factors (i.e., dependency). ISM is "a process that transforms unclear and poorly articulated mental models of systems into visible, welldefined models useful for many purposes" (Sushil, 2012, p. 88), which involves several steps to be taken to develop the ultimate ISM model. 


\section{Developing ISM model}

Step 1: Step one requires the identification of key configurational components of the topic of interest. Accordingly, through a careful review of comparative literature and synthesis of findings, key factors determining AOA are listed (Table 1).

Table 1. Key configurational factors of $A O A$

\begin{tabular}{|c|c|c|}
\hline Criteria & Definition & Authors \\
\hline $\begin{array}{l}\text { Organizational } \\
\text { characteristics } \\
(\mathrm{OC})\end{array}$ & $\begin{array}{l}\text { OC defines an organization's internal resources } \\
\text { and competencies that affect members' job } \\
\text { attitudes and behaviors (Turban \& Keon, 1993). } \\
\text { An airline company may involve factors including } \\
\text { safety image; reputation; airline size; airline work } \\
\text { environment; airline nationality, location, and } \\
\text { geographical dispersion. }\end{array}$ & $\begin{array}{l}\text { Allen and O'Brien (2006); Cable and } \\
\text { Judge (1996); Chapman et al. (2005); } \\
\text { Gomes and Neves (2011); Highhouse et } \\
\text { al. (2003); Kröll et al. (2018); Lievens et al. } \\
\text { (2001); Nadler et al. (2017); Rynes and } \\
\text { Barber (1990); Sivertzen et al. (2013); } \\
\text { Sohn et al. (2015); Spitzmüller et al. } \\
\text { (2008); Turban and Keon (1993); van } \\
\text { Prooijen and Ellemers (2015). }\end{array}$ \\
\hline $\begin{array}{l}\text { Job characteristics } \\
\text { (JC) }\end{array}$ & $\begin{array}{l}\text { JC refers to "the content and nature } \\
\text { of the tasks themselves" (Spector, 1997, p. 31) and } \\
\text { typically involves training, empowerment, } \\
\text { rewards and compensation, pay, job security, and } \\
\text { promotion. }\end{array}$ & $\begin{array}{l}\text { Chapman et al. (2005); Gomes and Neves } \\
\text { (2011); Kröll et al. (2018); Sivertzen et al. } \\
\text { (2013); Sohn et al. (2015); Spitzmüller et } \\
\text { al. (2008). }\end{array}$ \\
\hline Perceived fit & $\begin{array}{l}\text { Perceived fit usually involves two subsets in terms } \\
\text { of person-organization fit, defined as the level of } \\
\text { congruency between one's values and those of the } \\
\text { organization, and person-job fit defined as the } \\
\text { level of compatibility between one's values and } \\
\text { those of the job/task (Cable \& Judge, 1996). }\end{array}$ & $\begin{array}{l}\text { Cable and Judge (1996); Carless (2005); } \\
\text { Judge and Cable (1997); Sivertzen et al. } \\
\text { (2013); Yu (2014). }\end{array}$ \\
\hline $\begin{array}{l}\text { Corporate social } \\
\text { responsibility } \\
(\mathrm{CSR})\end{array}$ & $\begin{array}{l}\text { CSR is a "concept whereby companies integrate } \\
\text { social and environmental concerns in their } \\
\text { business operations and their interaction with } \\
\text { their stakeholders voluntary" (Dahlsrud, 2008, p. } \\
\text { 7), often composed of human rights, philanthropy, } \\
\text { environmental issues, employee relations, and } \\
\text { diversity management. }\end{array}$ & $\begin{array}{l}\text { Albinger and Freeman (2000); Backhaus } \\
\text { et al., (2002); Belinda et al. (2018); Duarte } \\
\text { et al. (2014); Joo et al. (2016); Lis (2018); } \\
\text { Murray and Ayoun (2010); Sivertzen et } \\
\text { al. (2013); Sohn et al. (2015); Story et al. } \\
\text { (2016); Umphress et al. (2007); Waples } \\
\text { and Brachle (2020); Zhang et al. (2020). }\end{array}$ \\
\hline $\begin{array}{l}\text { Corporate } \\
\text { branding }(\mathrm{CB})\end{array}$ & $\begin{array}{l}\text { CB refers to "creating an organization's unique } \\
\text { characteristics" (De Chernatony, 2001; Rode \& } \\
\text { Vallaster, 2005, p. 121), representing factors in } \\
\text { terms of image and prestige, positioning, value } \\
\text { proposition, advertisement, and public relations. }\end{array}$ & $\begin{array}{l}\text { Cober et al. (2003); Held and Bader } \\
\text { (2018); Jiang and Iles (2011); Lin (2015); } \\
\text { Van Hoye and Lievens (2005); Younis } \\
\text { and Hammad (2020). }\end{array}$ \\
\hline
\end{tabular}

Step 2: A matrix of the contextual relationship and interaction among a set of listed AOA factors should be established. According to Eq. 1, the matrix will comprise ten pairwise comparisons among five components of AOA.

$x=\frac{n(n-1)}{2}=5(5-1) / 2=10$ 
with $n$ representing the number of designated factors in the proposed configuration of the AOA model.

Step 3: Having designed the matrix, a panel of experts, including industry experts in the Iranian aviation and airline industry, were invited to fill in the matrix. A judgmental sample of 28 experts was invited for data collection. According to Etikan et al. (2016, p. 2), judgmental sampling "is the deliberate choice of a participant due to the qualities the participant possesses." A copy of the questionnaire with a cover letter explaining the study's aims and objectives and ensuring the confidentiality of data was sent to the experts. As shown in Table 2, Sixteen airline experts from Iran agreed to participate as panel members and completed the questionnaire. A sample of the questionnaire can be found in the appendix.

Table 2. Features of the study sample

\begin{tabular}{lll}
\hline Airline* & Position & Tenure \\
\hline A1 & Executive HR manager & More than 15 years \\
A1 & General marketing manager & More than 15 years \\
A1 & Head of operations department & More than 15 years \\
A1 & Head of cabin services & More than 15 years \\
A2 & Marketing and business development director & More than 10 years \\
A2 & Senior marketing officer & More than 10 years \\
A2 & Senior HR executive officer & More than 10 years \\
A3 & Head of the training department & More than 15 years \\
A3 & Operations manager & More than 10 years \\
A3 & Head of business and policy development unit & More than 10 years \\
A4 & Head of business and marketing department & More than 10 years \\
A4 & General HR manager & More than 18 years \\
A4 & Senior HR development officer & More than 10 years \\
A4 & International affairs director & More than 15 years \\
A5 & Executive research and development officer & More than 15 years \\
A5 & Head of operations department & More than 18 years \\
\hline * Due to the confidentiality of data collection, the names of participating airlines are kept anonymous.
\end{tabular}

Accordingly, a structural self-interaction matrix (SSIM) of AOA factors was built (Table 3), which contained several pairwise comparisons among AOA factors. Following notations have been proposed to the expert panel to address interrelations among AOA factors.

- If the row listed $\mathrm{i}$ facilitates reaching the factor in the column listed $\mathrm{j} ; \mathrm{V}$ will be inserted.

- If the factor in the row listed i can be obtained by the column listed j; A will be inserted.

- If the factor in the row listed $i$ and factor in the column listed $j$ help to reach each other; $X$ will be inserted; and 
- If the factor in the column listed $i$ and the factor in the column listed $j$ are unrelated, $\mathrm{O}$ will be inserted.

Table 3. Structural self-interaction matrix (SSIM)

\begin{tabular}{lccccc}
\hline Issues & OC & JC & Perceived fit & CSR & Branding \\
\hline Organizational characteristics (OC) & V & V & V & V & V \\
Job characteristics (JC) & A & V & V & O & O \\
Perceived fit & A & A & V & O & O \\
Corporate social responsibility (CSR) & A & O & O & V & X \\
Branding & A & O & O & X & V \\
\hline
\end{tabular}

Step 4: As required by ISM, at this step, a reachability matrix should be built and transitivity among relationships must be checked (i.e., if factor A is linked to factor B and factor B is linked to factor C, then factor A is linked to factor $\mathrm{C}$ ). As shown in Table 4, binary digits should be replaced by the notation as mentioned above.

Table 4. Binary digits

\begin{tabular}{lcccc}
\hline & Notation & $\begin{array}{c}\text { Reciprocal } \\
\text { notation }\end{array}$ & $\begin{array}{c}\text { Numeric } \\
\text { value }\end{array}$ & $\begin{array}{c}\text { Reciprocal numeric } \\
\text { value }\end{array}$ \\
\hline $\mathrm{i}$ improves $\mathrm{j}$ & $\mathrm{V}$ & $\mathrm{A}$ & 1 & 0 \\
$\mathrm{i}$ and $\mathrm{j}$ are not related & $\mathrm{O}$ & $\mathrm{O}$ & 0 & 0 \\
$\mathrm{i}$ and $\mathrm{j}$ are interrelated & $\mathrm{X}$ & $\mathrm{X}$ & 1 & 1 \\
\hline
\end{tabular}

Table 5. Initial reachability matrix

\begin{tabular}{lccccc}
\hline Issues & OC & JC & Perceived fit & CSR & Branding \\
\hline Organizational characteristics (OC) & $\mathbf{1}$ & 1 & 1 & 1 & 1 \\
Job characteristics (JC) & 0 & $\mathbf{1}$ & 1 & 0 & 0 \\
Perceived fit & 0 & 0 & $\mathbf{1}$ & 0 & 0 \\
Corporate social responsibility (CSR) & 0 & 0 & 0 & $\mathbf{1}$ & 1 \\
Branding & 0 & 0 & 0 & 1 & $\mathbf{1}$ \\
\hline
\end{tabular}

Table 6. Final reachability matrix

\begin{tabular}{|c|c|c|c|c|c|c|}
\hline Issues & OC & $\mathrm{JC}$ & Perceived fit & CSR & Branding & Driving Power \\
\hline Organizational characteristics (OC) & 1 & 1 & 1 & 1 & 1 & 5 \\
\hline Job characteristics (JC) & 0 & 1 & 1 & $1^{*}$ & $1^{*}$ & 4 \\
\hline Perceived fit & 0 & 0 & 1 & $1^{*}$ & $1^{*}$ & 3 \\
\hline $\begin{array}{l}\text { Corporate social } \\
\text { (CSR) }\end{array}$ & 0 & 0 & 0 & 1 & 1 & 2 \\
\hline Branding & 0 & 0 & 0 & 1 & 1 & 2 \\
\hline Dependency & 1 & 2 & 3 & 5 & 5 & \\
\hline
\end{tabular}


The initial reachability matrix is illustrated in Table 5. Using Table 4 and the adaption of the rule of transitivity, the final reachability matrix has been developed (Table 6).

Step 5: The final reachability matrix will be partitioned into hierarchical levels. Partitioning factors in various levels will help to build the hierarchy of ISM, using the intersections between reachability set (i.e., considering factor "A," the reachability set would be containing factor "A" itself and other factors which are affected by factor "A") and the antecedent set (i.e., considering factor " $Y$," the antecedent set would be containing factor " $Y$ " itself and other factors affecting it). This process continues in several iterations till there will be no more factors left for partitioning. The results of the four iterations are provided in Tables 7-10.

Table 7. Level partition (Iteration 1)

\begin{tabular}{lllll}
\hline Issues & Reachability set & Antecedent set & Intersection & Level \\
\hline Organizational characteristics (OC) & $1,2,3,4,5$ & 1,5 & 1,5 & \\
Job characteristics (JC) & $2,3,4,5$ & 1,2 & 1,2 & \\
Perceived fit & $3,4,5$ & $1,2,3$ & 3 & \\
Corporate social responsibility (CSR) & 4,5 & $1,2,3,4,5$ & 4,5 & I \\
Branding & 4,5 & $1,2,3,4,5$ & 4,5 & I \\
\hline
\end{tabular}

Table 8. Level partition (Iteration 2)

\begin{tabular}{lllll}
\hline Issues & Reachability set & Antecedent set & Intersection & Level \\
\hline Organizational characteristics (OC) & $1,2,3$ & 1 & 1,5 & \\
Job characteristics (JC) & 2,3 & 1,2 & 2 & II \\
Perceived fit & 3 & $1,2,3$ & 3 & . \\
\hline
\end{tabular}

Table 9. Level partition (Iteration 3)

\begin{tabular}{lllll}
\hline Issues & Reachability set & Antecedent set & Intersection & Level \\
\hline Organizational characteristics (OC) & 1,2 & 1 & 1 & \\
Job characteristics (JC) & 2 & 1,2 & 2 & III \\
\hline
\end{tabular}

Table 10. Level partition (Iteration 4)

\begin{tabular}{lllll}
\hline Issues & Reachability set & Antecedent set & Intersection & Level \\
\hline Organizational characteristics $(\mathrm{OC})$ & 1 & 1 & 1 & IV \\
\hline
\end{tabular}

Step 6: A directed graph should be established at this step, and then the transitive relations should be checked to obtain the ultimate ISM model. The ultimate hierarchical ISM is represented in Figure 1. 


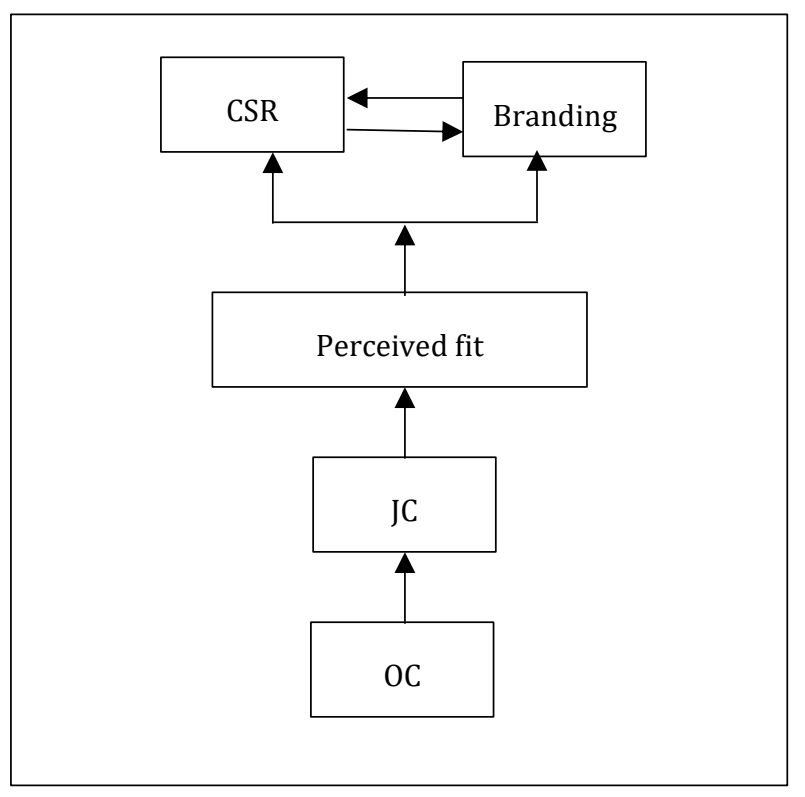

Figure 1. Interpretive structural model of $A O A$

Step 7: As the final step, the ISM model should be checked for logical inconsistencies, and if any, the corrections should be made. Hence, the ultimate ISM model results were sent back to the expert panel members to check for possible logical inconsistencies. There were no major concerns regarding the feasibility of configuration and interrelations of the factors in ISM. Therefore, no changes were made to the model.

\section{The application of MICMAC}

This study also applied MICMAC to clarify and simplify ISM results (Duperrin \& Godet, 1973; Warfield, 1974, 1994). As shown in Figure 2, MICMAC contains four clusters defining each factor's position in the ISM hierarchy. Factors at the bottom of the hierarchy would usually be found in Clusters I and/or IV. These factors show low dependency on other factors in the model while having a range of driving power over other factors. By moving upwards to the top of the hierarchy, factors will show both the characteristics of dependency and driving power over other factors (Cluster III characterized with high driving and high dependence power). These factors are linking autonomous and independent criteria to other criteria in upper levels of the hierarchy. However, factors positioned at the top of the hierarchy usually fall into Cluster II known as dependent criteria with high dependence power and low driving power. 


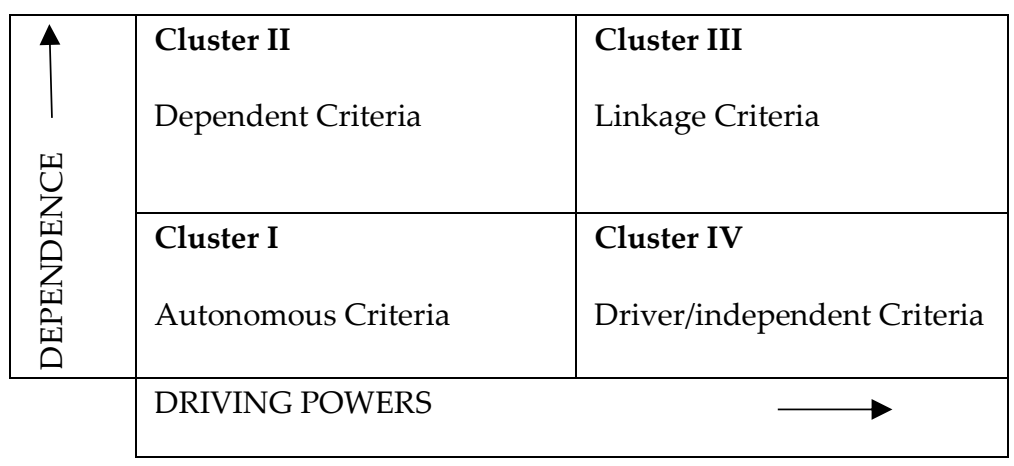

Figure 2. Basic graphical representation of MICMAC analytical tool

Under these circumstances, MICMAC analysis results revealed that organizational characteristics are the most significant factor in the ISM hierarchy with the strongest driving power over other factors. Job characteristics have been shown to demonstrate the same power with organizational characteristics sharing the same cluster (i.e., Cluster IV). Perceived fit has fallen in the middle of the matrix with moderate dependency on organizational and job characteristics and moderate driving power over corporate branding and CSR. This factor eventually represents the characteristics of a linkage factor connecting criteria at the lower levels of the hierarchy to the higher levels. Corporate branding and CSR are positioned as dependent factors in Cluster II while having interrelations with each other at the same level. These factors are not only affected by the manipulation of lower-level factors but are also reinforcing each other at the top of the hierarchy. A graphical representation of MICMAC analysis is provided in Figure 3.

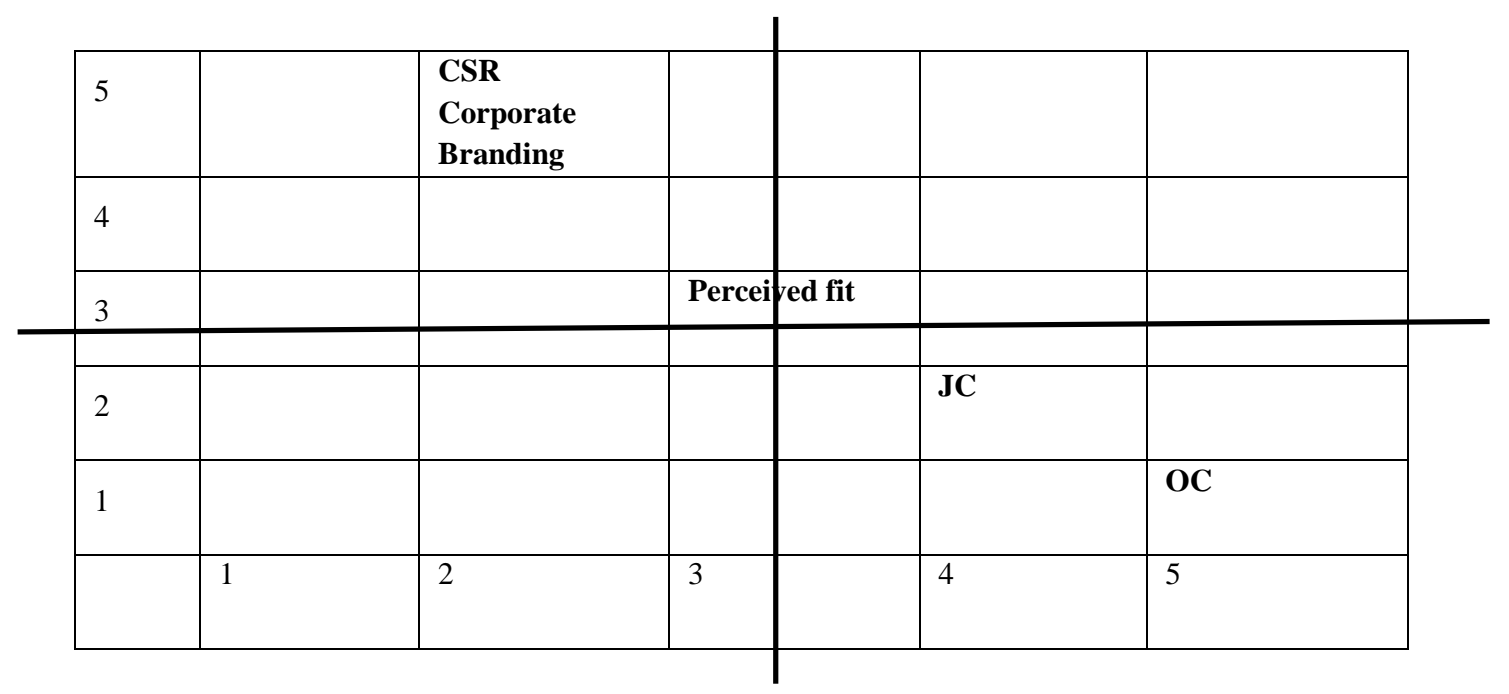

Figure 3. MICMAC analysis for airline attractiveness attributes 


\section{DISCUSSION}

Airline companies are struggling to survive the highly fragmented air transportation market. It has been noticed that the industry is showing a great net profit of $\$ 30$ billion with an 8 percent return on invested capital, which makes this industry attractive to potential investors (IATA annual report, 2019). Therefore, a sustained competitive position is a critical strategic practice for airline managers at various managerial levels. Specifically, qualified and talented human resources are considered significant competitiveness sources for airline companies (Chen \& Chang, 2005; Erkmen \& Hancer, 2015). According to Yeh (2014), high-performing frontline service employees in the airline industry would affect airline performance through enhanced customer interactions and services. Therefore, it seems plausible for airlines to invest in strategic ways of attracting and retaining qualified and talented job seekers. Enhancing organizational attractiveness in the job market may be considered as a remedy to the war for talent. This is especially the case for the airline industry, to which less talented graduates are attracted. This may be because airline occupations are confronted by challenging characteristics of aviation occupations in terms of long night shifts, stress, jetlag, and workfamily conflict (Chen \& Kao, 2011; Hsu \& Liu, 2012; Ng et al., 2011) and the knowledge and skills they acquire as airline employee may rarely be transferable to other industries (Liang \& Hsieh, 2005; Vatankhah et al., 2017).

Against this background, this study provided an insight into the key factors fostering OA in the airline industry. In addition, this study applied ISM and MICMAC to further analyze the interrelations among identified factors. It appears that all five factors are significantly improving AOA. Particularly, organizational characteristics have been found as the most determining factor affecting job seekers' attraction to the airline. Job characteristics display the second most significant factor with which job seekers evaluate the vacancy and ultimately attract the airline. According to Turban and Keon (1993), job seekers are attracted to organizations based on perceived fit with the organization's job. The current study's findings are consistent with this argument, positioning perceived fit as the linkage factor. A job seeker would primarily evaluate organizational and job characteristics, and their intentions to pursue the job will be tackled if they perceived fit between their norms and values and those of the organization and the job. Finally, corporate branding and CSR are the last two factors determining how a qualified job seeker is attracted to the airline. According to the results, proper CSR adoption would strengthen the image of the 
airline and at the same time, proper branding strategies should be more focused on CSR practices. Job seekers and talented graduates are processing their information from corporate branding efforts and CSR activities. A brief discussion on interrelations among key factors is provided in Table 11. In all, proper design of organizational and job characteristics improves job seekers' perceived fit with both the organization and the job, ultimately resulting in a positive interpretation of corporate branding strategies and CSR efforts.

Table 11. Interpretive matrix

\begin{tabular}{|c|c|c|c|c|c|}
\hline Issues & $\mathrm{OC}$ & $\mathrm{JC}$ & Perceived fit & CSR & Branding \\
\hline $\begin{array}{l}\text { Organizational } \\
\text { characteristics } \\
(\mathrm{OC})\end{array}$ & - & $\begin{array}{l}\text { Supportive rules } \\
\text { and regulations } \\
\text { may positively } \\
\text { affect the proper } \\
\text { design of aviation } \\
\text { jobs/tasks. }\end{array}$ & $\begin{array}{l}\text { Organizational norms } \\
\text { and values can be } \\
\text { managed to align with } \\
\text { the norms and values } \\
\text { of the prospective job } \\
\text { market. }\end{array}$ & $\begin{array}{l}\text { Supportive } \\
\text { strategies, } \\
\text { rules, and } \\
\text { practices } \\
\text { concerning } \\
\text { CSR }\end{array}$ & $\begin{array}{l}\text { Supportive } \\
\text { strategies, } \\
\text { rules, and } \\
\text { practices } \\
\text { concerning } \\
\text { corporate } \\
\text { branding. } \\
\end{array}$ \\
\hline $\begin{array}{l}\text { Job characteristics } \\
\text { (JC) }\end{array}$ & 0 & - & $\begin{array}{l}\text { Proper design of the } \\
\text { job in terms of job } \\
\text { demands may } \\
\text { positively influence job } \\
\text { seekers' perceived fit } \\
\text { with the job. }\end{array}$ & $\begin{array}{l}\text { Appropriate } \\
\text { job design may } \\
\text { encourage } \\
\text { employee } \\
\text { prosocial and } \\
\text { pro- } \\
\text { environmental } \\
\text { values and } \\
\text { initiatives }\end{array}$ & Transitive \\
\hline Perceived fit & 0 & 0 & - & Transitive & Transitive \\
\hline $\begin{array}{l}\text { Corporate social } \\
\text { responsibility } \\
(\mathrm{CSR})\end{array}$ & 0 & 0 & 0 & - & $\begin{array}{l}\text { CSR initiatives } \\
\text { should be } \\
\text { reflected in } \\
\text { corporate } \\
\text { branding. }\end{array}$ \\
\hline $\begin{array}{l}\text { Corporate } \\
\text { branding }\end{array}$ & 0 & 0 & 0 & $\begin{array}{l}\text { Corporate } \\
\text { branding } \\
\text { strategies } \\
\text { should be } \\
\text { aligned with } \\
\text { CSR } \\
\text { philosophy. }\end{array}$ & - \\
\hline
\end{tabular}

\section{Theoretical contributions}

Organizational attractiveness is well known for its ability to attract and retain a talented pool of job seekers. It is especially the case for the airline industry that seems to suffer from the lack of well-educated job seekers (Sohn et al., 2015) and high level of turnover rates (Chen, 2006; Karatepe \& Vatankhah, 2014a; Schiffinger \& Braun, 2020). This study adds to the ongoing debate in organizational attractiveness literature by developing an ISM that identified main factors affecting AOA as manifested through OC, 
JC, Perceived fit, CSR, and Corporate branding. In addition, the study contributes to the theory by unraveling the classification of identified factors via MICMAC. Specifically, JC and OC were found to the most powerful drivers of AOA. This is followed by Perceived fit that links the drivers to dependent factors in terms of CSR and Corporate Branding.

\section{Implications}

The proposed hierarchy of factors fostering AOA may be considered as the major theoretical contribution of the current study by enhancing the current understanding of the fundamental building blocks of AOA and the process by which they are related to each other. Nevertheless, ISM is a decisionmaking tool that helps managers practically decide on the problem's best solution. This technique is used to understand how different components of a particular phenomenon may interact to enhance the positive outcome to its optimum level. Besides, MICMAC gives further insight into the driving power and dependency characteristics of each criterion. Hence, the results of ISM and MICMAC provide a handful of solutions for airline managers who are managing to attract and retain high-performing qualified job seekers. First, this study synthesized relative literature on organizational attractiveness and adapted the synthesis results into the airline industry context. The results revealed that five factors in terms of organizational characteristics, job characteristics, perceived fit, corporate social responsibility, and corporate branding are significant factors affecting AOA. Airlines should pay close attention to the proper design and management of these five factors. In a more detailed evaluation, organizational and job characteristics have been found as the two factors with the most driving power in the proposed model. Therefore, managers are encouraged to take into consideration factors such as organizational culture, dispersion of its plants, and rules and regulations to facilitate nextlevel factors, namely job characteristics. This is especially one factor that can be properly manipulated to increase its attractiveness for job seekers. Appropriate design of the job, demands, and responsibilities affiliated with the job, pay and promotions offered to actual and prospective employees, job security confidence, work-family balance, flexible work schedule are strategic solutions that may affect AOA. Airline occupations are known as job positions whose skills acquired during employment cannot be easily transferable to other occupations. Accordingly, as other functions of job characteristics, airline companies' managers are suggested to provide job security and training to cope with aviation occupations' negative features (Karatepe \& Vatankhah, 2014b). 
In addition, the results of our study noted the significance of fit perception and OA in the airline industry. Therefore, several orientation programs would be needed to enhance job seekers' familiarity with the nature of the job and the organization's features. Besides, airline companies should attract job seekers who show relatively appropriate personality traits and aptitude. According to Goeters et al. (1993, p. 123), "basic aptitudes and personality traits are both important in determining the professional reliability of human operators" in the aviation industry. Careful analysis of prospective job seekers' personality traits would facilitate fit perception and ultimately foster applicants' attraction and retention.

Corporate branding, known as a precursor of economic success and survival (Mollerup, 1998), may also foster job seekers' attraction to the airline company. Specifically, advertisement and mission statement preparation should be focused on appealing to the airline's organizational and job characteristics to promote fit perception. Rebranding is a common practice among international airlines striving to sustained profitability in the air transportation market (Thurlow \& Aiello, 2007).

In addition, branding should be aligned with CSR activities as there is rising concern among young graduates to choose socially responsible organizations and their actions are in line with reduced energy consumption and pollution (Albinger \& Freeman, 2000; Duarte et al., 2014). For example, a "multicultural" branding strategy can be taken into consideration to support diversity management as a core component of CSR initiatives, or the CSR philosophy can be reflected in the airline's commercially important symbols (e.g., the design of tailfins) (Thurlow \& Aiello, 2007).

Success in organizational performance is highly associated with the quality and performance of its internal resources, of which human resources are considered valuable living assets of any organization. With a particular emphasis on human resources, service industries, including the airline industry, should invest in its human capital quality through proper design of organizational and job characteristics, enhanced fit perception, corporate branding, and CSR efforts. The proper adoption of relative strategies offered in ISM and the emphasis on the priority and driving power of one criterion over the other would act as a strategic tool for airline managers who are struggling to improve their competitive position in the air transportation market. 


\section{Limitations and future research directions}

This study faced several limitations offering opportunities for further analysis. That is, key compositional components of AOA have been identified from the extant literature. However, the literature about the factors fostering $\mathrm{AOA}$ was scarce and the general configuration of criteria was adapted from various industries. Accordingly, it is highly suggested to make a fuzzy Delphi study to strengthen the primary list of factors based on the results of an in-depth interview. This would validate the finding at the first step (Koc \& Boz, 2014). This study also used the Iranian airline industry as the context of the study. The study's single contextual and cultural approach may raise the issue of the generalizability of findings to other contexts. Therefore, it seems reasonable to replicate the study in other industries and other countries with different cultural backgrounds (e.g., China, Germany) to understand if contextual and cultural differences matter in the configuration of and interrelations among key factors affecting OA. Finally, the current article addressed significant factors which can improve airline attractiveness. However, some factors may also exist that act as barriers to airline attractions. Investigating barriers to airline attractiveness may contribute to the knowledge base by addressing barriers and proposing strategies to cope with those barriers.

\section{REFERENCES}

Albinger, H. S., \& Freeman, S. J. (2000). Corporate social performance and attractiveness as an employer to different job seeking populations. Journal of Business Ethics, 28(3), 243-253.

Ali, S. M., Arafin, A., Moktadir, M. A., Rahman, T., \& Zahan, N. (2018). Barriers to reverse logistics in the computer supply chain using interpretive structural model. Global journal of flexible systems management, 19(1), 53-68.

Allen, T. D., \& O'Brien, K. E. (2006). Formal mentoring programs and organizational attraction. Human Resource Development Quarterly, 17(1), 43-58.

Attri, R., Dev, N., \& Sharma, V. (2013). Interpretive structural modelling (ISM) approach: an overview. Research Journal of Management Sciences, 2319, 1171.

Backhaus, K. B. (2016). Organizational identity, corporate social performance and corporate reputation: Their roles in creating organizational attractiveness. In Corporate Reputation (pp. 127-146). Routledge.

Backhaus, K. B., Stone, B. A., \& Heiner, K. (2002). Exploringthe relationship between corporate social performance and employer attractiveness. Business $\mathcal{E}$ Society, 41(3), 292-318.

Bankins, S., \& Waterhouse, J. (2019). Organizational identity, image, and reputation: Examining the influence on perceptions of employer attractiveness in public sector organizations. International Journal of Public Administration, 42(3), 218-229.

Belinda, C. D., Westerman, J. W., \& Bergman, S. M. (2018). Recruiting with ethics in an online era: Integrating corporate social responsibility with social media to predict organizational attractiveness. Journal of Vocational Behavior, 109, 101-117. 
Bohlmann, C., Krumbholz, L., \& Zacher, H. (2018). The triple bottom line and organizational attractiveness ratings: The role of pro-environmental attitude. Corporate Social Responsibility and Environmental Management, 25(5), 912919.

Bretz Jr, R. D., \& Judge, T. A. (1994). The role of human resource systems in job applicant decision processes. Journal of Management, 20(3), 531-551.

Brunner, C. B., \& Baum, M. (2020). The impact of brand portfolios on organizational attractiveness. Journal of Business Research, 106, 182-195.

Cable, D. M., \& Judge, T. A. (1996). Person-organization fit, job choice decisions, and organizational entry. Organizational behavior and human decision processes, 67(3), 294-311.

Caldwell, D. F., \& O'Reilly III, C. A. (1990). Measuring person-job fit with a profilecomparison process. Journal of applied psychology, 75(6), 648.

Carballo-Penela, A. (2019). Enhancing social sustainability at a business level: Organizational attractiveness is higher when organizations show responsibility towards employees. Business Strategy \& Development, 2(4), 372-383.

Carless, S. A. (2005). Person-job fit versus person-organization fit as predictors of organizational attraction and job acceptance intentions: A longitudinal study. Journal of Occupational and Organizational Psychology, 78(3), 411-429.

Chapman, D. S., Uggerslev, K. L., Carroll, S. A., Piasentin, K. A., \& Jones, D. A. (2005). Applicant attraction to organizations and job choice: a meta-analytic review of the correlates of recruiting outcomes. Journal of applied psychology, 90(5), 928.

Chen, C. F. (2006). Job satisfaction, organizational commitment, and flight attendants' turnover intentions: A note. Journal of Air Transport Management, 12(5), 274-276.

Chen, C. F., \& Kao, Y. L. (2011). The antecedents and consequences of job stress of flight attendants-Evidence from Taiwan. Journal of Air Transport Management, 17(4), 253255.

Chen, F. Y., \& Chang, Y. H. (2005). Examining airline service quality from a process perspective. Journal of Air Transport Management, 11(2), 79-87.

Cober, R. T., Brown, D. J., Levy, P. E., Cober, A. B., \& Keeping, L. M. (2003). Organizational web sites: Web site content and style as determinants of organizational attraction. International Journal of Selection and Assessment, 11(2-3), 158-169.

Cowper-Smith, A., \& de Grosbois, D. (2011). The adoption of corporate social responsibility practices in the airline industry. Journal of Sustainable Tourism, 19(1), 59-77.

Dahlsrud, A. (2008). How corporate social responsibility is defined: an analysis of 37 definitions. Corporate social responsibility and environmental management, 15(1), 1-13.

De Chernatony, L. (2001). A model for strategically building brands. Journal of brand management, 9(1), 32-44.

De Chernatony, L. (1999). Brand management through narrowing the gap between brand identity and brand reputation. Journal of marketing management, 15(1-3), 157-179.

Denzin, N. K. (2017). The research act: A theoretical introduction to sociological methods. Routledge.

Denzin, N. K. (2007). Triangulation. The Blackwell Encyclopedia of Sociology.

Duarte, A. P., Gomes, D. R., \& das Neves, J. G. (2014). Tell me your socially responsible practices, I will tell you how attractive for recruitment you are! The impact of perceived CSR on organizational attractiveness. Tékhne, 12, 22-29.

Duperrin, J. C., \& Godet, M. (1973). Methode de hierarchisation des elements d'un systeme. Rapport Economique du CEA, Paris, 45-51. 
Erkmen, E., \& Hancer, M. (2015). Linking brand commitment and brand citizenship behaviors of airline employees: "The role of trust". Journal of Air Transport Management, 42, 47-54.

Etikan, I., Sulaiman, A. M., \& Rukayya, S. A. (2016). Comparison of convenience sampling and purposive sampling. American journal of theoretical and applied statistics 5(1), 14.

Goeters, K. M., Timmermann, B., \& Maschke, P. (1993). The construction of personality questionnaires for selection of aviation personnel. The International Journal of Aviation Psychology, 3(2), 123-141.

Gomes, D., \& Neves, J. (2011). Organizational attractiveness and prospective applicants' intentions to apply. Personnel Review, 40(6), 684-699.

Hartley, R. I., \& Sturm, P. (1997). Triangulation. Computer vision and image understanding, 68(2), 146-157.

Held, K., \& Bader, B. (2018). The influence of images on organizational attractiveness: comparing Chinese, Russian and US companies in Germany. The International Journal of Human Resource Management, 29(3), 510-548.

Helmreich, R. L., \& Foushee, H. C. (2010). Why CRM? Empirical and theoretical bases of human factors training. In Crew resource management (pp. 3-57). Academic Press.

Highhouse, S., Lievens, F., \& Sinar, E. F. (2003). Measuring attraction to organizations. Educational and Psychological Measurement, 63(6), 986-1001.

Hsu, Y. L., \& Liu, T. C. (2012). Structuring risk factors related to airline cabin safety. Journal of air transport management, 20, 54-56.

Honeycutt, T. L., \& Rosen, B. (1997). Family friendly human resource policies, salary levels, and salient identity as predictors of organizational attraction. Journal of Vocational Behavior, 50(2), 271-290.

Huang, L., Yang, Y., \& Sekiguchi, T. (2020). Attractiveness of Japanese firms to international job applicants: the effects of belongingness, uniqueness, and employment patterns. Asian Business \& Management, 19(1), 118-144.

IATA annual report (2019). Retrieved June 22, 2020, from https://www.iata.org/contentassets/c81222d96c9a4e0bb4ff6ced0126f0bb/iataannual-review-2019.pdf.

Jain, V., \& Ajmera, P. (2018). Modelling the factors affecting Indian medical tourism sector using interpretive structural modeling. Benchmarking: An International Journal, 25(5), 1461-1479.

Jiang, T., \& Iles, P. (2011). Employer-brand equity, organizational attractiveness and talent management in the Zhejiang private sector, China. Journal of Technology Management in China, 6(1), 97-110.

Joo, Y. R., Moon, H. K., \& Choi, B. K. (2016). A moderated mediation model of CSR and organizational attractiveness among job applicants: Roles of perceived overall justice and attributed motives. Management Decision, 54(6), 1269-1293.

Judge, T. A., \& Bretz, R. D. (1992). Effects of work values on job choice decisions. Journal of applied psychology, 77(3), 261.

Judge, T. A., \& Cable, D. M. (1997). Applicant personality, organizational culture, and organization attraction. Personnel Psychology, 50(2), 359-394.

Karatepe, O. M., \& Vatankhah, S. (2014a). The effects of high-performance work practices and job embeddedness on flight attendants' performance outcomes. Journal of Air Transport Management, 37, 27-35. 
Karatepe, O. M., \& Vatankhah, S. (2014b). The effects of high-performance work practices on perceived organizational support and turnover intentions: Evidence from the airline industry. Journal of Human Resources in Hospitality \& Tourism, 13(2), 103-119.

Kausel, E. E., \& Slaughter, J. E. (2011). Narrow personality traits and organizational attraction: Evidence for the complementary hypothesis. Organizational Behavior and Human Decision Processes, 114(1), 3-14.

Kristof-Brown, A. L., Zimmerman, R. D., \& Johnson, E. C. (2005). Consequences of individuals' fit at work: a meta-analysis of person-job, person-organization, person-group, and person-supervisor fit. Personnel Psychology, 58(2), 281-342.

Koc, E., \& Boz, H. (2014). Triangulation in tourism research: A bibliometric study of top three tourism journals. Tourism Management Perspectives, 12, 9-14.

Kröll, C., Nüesch, S., \& Foege, J. N. (2018). Flexible work practices and organizational attractiveness in Germany: The mediating role of anticipated organizational support. The International Journal of Human Resource Management, 1-30.

Kuo, T. C., Ma, H. Y., Huang, S. H., Hu, A. H., \& Huang, C. S. (2010). Barrier analysis for product service system using interpretive structural model. The International Journal of Advanced Manufacturing Technology, 49(1-4), 407-417.

Lambert, J. R., Basuil, D. A., Bell, M. P., \& Marquardt, D. J. (2019). Coming to America: work visas, international diversity, and organizational attractiveness among highly skilled Asian immigrants. The International Journal of Human Resource Management, 30(15), 2293-2319.

Lee, T. R., Kuo, Y. H., \& Muhos, M. (2015). Applying interpretive structural modeling to the planning of a sequence of marketing strategies: a case study of the architectural tourism in Taiwan. Asia Pacific Journal of Tourism Research, 20(10), 1132-1150.

Lewis, G. B., \& Frank, S. A. (2002). Who wants to work for the government? Public Administration Review, 62(4), 395-404.

Liang, S. C., \& Hsieh, A. T. (2005). Individual's perception of career development and job burnout among flight attendants in Taiwan. The International Journal of Aviation Psychology, 15(2), 119-134.

Lievens, F., Decaesteker, C., Coetsier, P., \& Geirnaert, J. (2001). Organizational attractiveness for prospective applicants: A person-organisation fit perspective. Applied Psychology, 50(1), 30-51.

Lin, H. F. (2015). The impact of company-dependent and company-independent information sources on organizational attractiveness perceptions. Journal of Management Development, 34(8), 941-959.

Lis, B. (2018). Corporate social responsibility's influence on organizational attractiveness: An investigation in the context of employer choice. Journal of General Management, 43(3), 106-114.

Maxwell, J. A. (2012). Qualitative research design: An interactive approach (Vol. 41). USA: Sage publications.

Miles, S. J., \& Mangold, W. G. (2005). Positioning Southwest Airlines through employee branding. Business Horizons, 48(6), 535-545.

Mollerup, P. (1998). Marks of Excellence: The History and Taxonomy of Trademarks. London: Phaidon Press.

Murray, D. W., \& Ayoun, B. M. (2010). Hospitality student perceptions on the use of sustainable business practices as a means of signaling attractiveness and attracting future employees. Journal of Human Resources in Hospitality \& Tourism, 10(1), 60-79. 
Nadler, J., Gann-Bociek, M., \& Skaggs, B. (2017). Interview support on perceptions of organizational attractiveness: The effects of applicant gender and socio-economic status. Management Research Review, 40(7), 783-799.

Ng, S. I., Sambasivan, M., \& Zubaidah, S. (2011). Antecedents and outcomes of flight attendants' job satisfaction. Journal of Air Transport Management, 17(5), 309-313.

Nur Iplik, F., Can Kilic, K., \& Yalcin, A. (2011). The simultaneous effects of personorganization and person-job fit on Turkish hotel managers. International Journal of Contemporary Hospitality Management, 23(5), 644-661.

Park, H. I., Monnot, M. J., Jacob, A. C., \& Wagner, S. H. (2011). Moderators of the relationship between person-job fit and subjective well-being among Asian employees. International Journal of Stress Management, 18(1), 67.

Petter, S. C., \& Gallivan, M. J. (2004). Toward a framework for classifying and guiding mixed method research in information systems. In 37th Annual Hawaii International Conference on System Sciences, 2004. Proceedings of the (pp. 10-pp). IEEE.

Ranjan Debata, B., Sree, K., Patnaik, B., \& Sankar Mahapatra, S. (2013). Evaluating medical tourism enablers with interpretive structural modeling. Benchmarking: An International Journal, 20(6), 716-743.

Rode, V., \& Vallaster, C. (2005). Corporate branding for start-ups: the crucial role of entrepreneurs. Corporate Reputation Review, 8(2), 121-135.

Rynes, S. L., \& Barber, A. E. (1990). Applicant attraction strategies: An organizational perspective. Academy of management review, 15(2), 286-310.

Rynes, S. L., \& Miller, H. E. (1983). Recruiter and job influences on candidates for employment. Journal of Applied Psychology, 68(1), 147-154.

Schiffinger, M., \& Braun, S. M. (2020). The impact of social and temporal job demands and resources on emotional exhaustion and turnover intention among flight attendants. Journal of Human Resources in Hospitality \& Tourism, 19(2), 196-219.

Schreurs, B., Druart, C., Proost, K., \& De Witte, K. (2009). Symbolic attributes and organizational attractiveness: The moderating effects of applicant personality. International Journal of Selection and Assessment, 17(1), 35-46.

Sivertzen, A.M., Nilsen, E.R. \& Olafsen, A.H. (2013). Employer branding: Employer attractiveness and the use of social media. Journal of Product and Brand Management, 22(7), 473-483.

Sohn, M., Sohn, W., Klaas-Wissing, T., \& Hirsch, B. (2015). The influence of corporate social performance on employer attractiveness in the transport and logistics industry: Insights from German junior talent. International Journal of Physical Distribution $\mathcal{E}$ Logistics Management, 45(5), 486-505.

Sommer, L. P., Heidenreich, S., \& Handrich, M. (2017). War for talents-How perceived organizational innovativeness affects employer attractiveness. RED Management, 47(2), 299-310.

Spector, P. E. (1997). Job satisfaction: Application, assessment, causes, and consequences (Vol. 3). Sage.

Spitzmüller, C., Neumann, E., Spitzmüller, M., Rubino, C., Keeton, K. E., Sutton, M. T., \& Manzey, D. (2008). Assessing the influence of psychosocial and career mentoring on organizational attractiveness. International Journal of Selection and Assessment, 16(4), 403-415.

Story, J., Castanheira, F., \& Hartig, S. (2016). Corporate social responsibility and organizational attractiveness: implications for talent management. Social Responsibility Journal, 12(3), 484-505. 
Sushil, S. (2012). Interpreting the interpretive structural model. Global Journal of Flexible Systems Management, 13(2), 87-106.

Thurlow, C., \& Aiello, G. (2007). National pride, global capital: A social semiotic analysis of transnational visual branding in the airline industry. Visual communication, 6(3), 305-344.

Turban, D. B., \& Greening, D. W. (1997). Corporate social performance and organizational attractiveness to prospective employees. Academy of Management Journal, 40(3), 658-672.

Turban, D. B., \& Keon, T. L. (1993). Organizational attractiveness: An interactionist perspective. Journal of Applied Psychology, 78(2), 184.

Umphress, E. E., Smith-Crowe, K., Brief, A. P., Dietz, J., \& Watkins, M. B. (2007). When birds of a feather flock together and when they do not: status composition, social dominance orientation, and organizational attractiveness. Journal of Applied Psychology, 92(2), 396.

Van Hoye, G., \& Lievens, F. (2005). Recruitment-related information sources and organizational attractiveness: Can something be done about negative publicity?. International Journal of Selection and Assessment, 13(3), 179-187.

van Prooijen, A. M., \& Ellemers, N. (2015). Does it pay to be moral? How indicators of morality and competence enhance organizational and work team attractiveness. British Journal of Management, 26(2), 225-236.

Vatankhah, S., Javid, E., \& Raoofi, A. (2017). Perceived organizational support as the mediator of the relationships between high-performance work practices and counter-productive work behavior: Evidence from airline industry. Journal of Air Transport Management, 59, 107-115.

Vatankhah, S., Zarra-Nezhad, M., \& Amirnejad, G. (2019). Tackling the fuzziness of business model concept: A study in the airline industry. Tourism Management, 74, 134-143.

Waples, C. J., \& Brachle, B. J. (2020). Recruiting millennials: Exploring the impact of CSR involvement and pay signaling on organizational attractiveness. Corporate Social Responsibility and Environmental Management, 27(2), 870-880.

Warfield, J. N. (1974). Developing interconnection matrices in structural modeling. IEEE Transactions on Systems, Man, and Cybernetics, (1), 81-87.

Warfield, J. N. (1994). Science of generic design: managing complexity through systems design. Iowa State Press.

Yeh, Y. P. (2014). Exploring the impacts of employee advocacy on job satisfaction and organizational commitment: Case of Taiwanese airlines. Journal of Air Transport Management, 36, 94-100.

Younis, R. A. A., \& Hammad, R. (2020). Employer image, corporate image and organizational attractiveness: the moderating role of social identity consciousness. Personnel Review, 50(1), 244-263.

Yu, K. Y. T. (2014). Person-organization fit effects on organizational attraction: A test of an expectations-based model. Organizational Behavior and Human Decision Processes, 124(1), 75-94.

Zhang, Q., Cao, M., Zhang, F., Liu, J., \& Li, X. (2020). Effects of corporate social responsibility on customer satisfaction and organizational attractiveness: A signaling perspective. Business Ethics: A European Review, 29(1), 20-34. 


\section{APPENDIX. SAMPLE QUESTIONNAIRE}

Section I: Instructions: Please use the following scale to indicate the relative impact of each criterion on the other one.

\begin{tabular}{|l|l|}
\hline Values & Explanation \\
\hline $\mathrm{V}$ & Factor listed in row $\mathrm{i}$ facilitates reaching the factor listed in the column $\mathrm{j}$ \\
\hline $\mathrm{A}$ & Factor listed in row $\mathrm{i}$ can be obtained by the factor listed in column $\mathrm{j}$ \\
\hline $\mathrm{X}$ & Factor listed in the row $\mathrm{i}$ and factor listed in the column $\mathrm{j}$ help to reach each other. \\
\hline $\mathrm{O}$ & Factor listed in the column $\mathrm{i}$ and the factor listed in the column $\mathrm{j}$ are unrelated. \\
\hline
\end{tabular}

Hint: Comparing factor A with factor B, the following table suggests that factor A would help to reach factor B.

\begin{tabular}{|l|l|l|}
\hline Factors & A & B \\
\hline A & - & V \\
\hline B & & - \\
\hline
\end{tabular}

\section{Section II: Factors}

1. Organizational characteristics (OC)

2. Job characteristics (JC)

3. Perceived fit

4. Corporate social responsibility (CSR)

5. Branding

\begin{tabular}{|l|l|l|l|l|l|}
\hline Factors & OC & JC & Perceived fit & CSR & Branding \\
\hline Organizational characteristics (OC) & - & & & & \\
\hline Job characteristics (JC) & & - & & & \\
\hline Perceived fit & & & - & & \\
\hline Corporate social responsibility (CSR) & & & & - & \\
\hline Branding & & & & & - \\
\hline
\end{tabular}

